\title{
Efecto de las puzolanas naturales en la porosidad y conectividad de poros del hormigón con el tiempo
}

\section{Effect of natural pozzolans on porosity and pore connectivity of concrete with time}

\author{
Mauricio López*1, José Tomás Castro** \\ * Pontificia Universidad Católica de Chile, Santiago. CHILE \\ * R\&Q Ingeniería, Santiago. CHILE
}

Fecha de recepción: 01/ 11/ 2010 Fecha de aceptación: 01/ 12/ 2010

Resumen

\begin{abstract}
Los materiales puzolánicos adicionados a las mezclas de hormigón con cemento portland reaccionan con la portlandita formando nuevos silicatos de calcio hidratados los pueden mejorar la durabilidad de estructuras de hormigón. Con el objetivo de mejorar el entendimiento del rol de las puzolanas naturales en el desempeño del hormigón, este estudio caracterizó la porosidad e interconectividad de los poros de hormigones en función del contenido de puzolanas naturales. El programa experimental caracterizó la resistencia y permeabilidad de hormigones con diferentes contenidos de puzolanas y con edades entre 28 y 84 días para así evaluar el efecto de las puzolanas en función del tiempo. Los resultados muestran que la ganancia en impermeabilidad debido al uso de puzolanas naturales es muy superior al efecto observado en resistencia. Por ejemplo, hormigones con $33 \%$ de puzolanas en reemplazo del cemento presentaron una resistencia a compresión $27 \%$ inferior a la del hormigón sin puzolanas; sin embargo, su impermeabilidad fue aproximadamente $200 \%$ superior a las de los hormigones sin puzolanas. Los ensayos de permeabilidad a iones cloruro y absorción capilar, presentaron baja variabilidad y buena correlación con las reacciones puzolánicas. Se concluye que se debe controlar independientemente la permeabilidad y la resistencia del hormigón ya que son afectadas de manera diferente por las reacciones puzolánicas; además, se concluye que para considerar el efecto de las puzolanas se debe ensayar permeabilidad a edades tardías.
\end{abstract}

Palabras Clave: Puzolanas, ión cloruro, capilaridad, permeabilidad, durabilidad

Abstract

Pozzolanic materials in portland cement concrete mixtures hydrate forming new calcium silicate hydrates which improve durability of concrete structures. The aim of this research was to enhance the understanding of the role of natural pozzolans in concrete performance. This study characterized porosity and pore connectivity of concrete mixtures as function of the content of natural pozzolans. The experimental program measured compressive strength and permeability of concrete mixtures with different levels of cement replacement by natural pozzolans between 28 and 84 days of age, so the effect of pozzolans could be assessed as a function of time. Results clearly show that the gain in impermeability of concrete due to the use of natural pozzolans is much more pronounced that the effect in compressive strength. For instance, concrete with 33\% of cement replaced by natural pozzolans had a compressive strength $27 \%$ lower that those with no pozzolans replacement; nevertheless, their impermeability was approximately $200 \%$ superior to those with no pozzolans replacement. Chloride ion permeability and rate of water absorption showed low variability and good correlation with pozzolanic reactions. It can be concluded that it is important to control compressive strength and permeability independently because they are affected very differently by pozzolanic reactions; also, for taking advantage of natural pozzolans in concrete, it is important to specify and measure permeability at late ages.

Keywords: Pozzolans, chloride ion, rate of absorption, permeability, durability

\section{Introduction}

\subsection{Concrete durability}

Durability on a concrete structure is a quite complex variable, which simultaneously depends on several factors. Such factors may be classified into two groups: those related with the environment to which the structure is exposed to and those related to the characteristics of concrete itself.

\footnotetext{
${ }^{1}$ Autor de correspondencia / Corresponding author: 
The environmental factors, to which the structure is exposed to, include variables such as applied stress to the structure, aggressive environmental conditions related to concrete, weather conditions in the work site and, specific events such as fire high temperatures or severe strain due to an earthquake. As far as environmental factors where the structure is exposed to, the following may be found: factors related with project execution level (tools employed, materials to be used, dosages, constructive method, construction specifications and techniques) as well as structures maintenance programs.

These two factor groups must be considered at the project design in order to fulfill the operating life requirements for the structure. It becomes evident to consider environmental factors where the structure is exposed to as a macro aspect difficult to manage by the parties involved in the project. It is then possible to influence in concrete characteristics to control project durability.

If concrete characteristics are isolated and attention is only drawn to the type of concrete to be used in structures, durability will depend on the ability of such material to stay in good conditions and to resist deterioration attacks. These agents only deteriorate concrete when they are able to penetrate its microstructure. That is the reason why the main variable to be considered, for obtaining long lasting concrete, is porosity and pore connectivity which finally determine its permeability, (Mehta P.K. and P.J.M. Monteiro, 2006).

1.2 Supplementary cementitious materials and durability Concrete technology has undergone major advances in recent times. The most outstanding changes are centered in the development of new chemical admixtures to modify fresh and hardened concrete properties as well as the supplementary cementitious materials (SCM 's) or mineral admixtures as support and/or complement to Portland cement.

SCM's come from several sources and have different effects on fresh and hardened concrete properties. The most common SCM's presently used are silica fume (sub-product from ferrous-silica alloy industry); granulate blast furnace slag (sub-product from steel fabrication) and fly ash (sub-product from coal fired power stations). 
Besides artificial sources-SCM 's, there are some others from natural sources such as clays (metakaolin) and natural volcanic pozzolans, which are fully available in Central America and South America commonly used in some countries of such region (Mehta P.K. and P.J.M. Monteiro, 2006; N eville A.M., 1996).

SCM 's may produce hydraulic and pozzolanic reactions. The first ones are chemical reactions due to hydration that enable hardening which is a similar reaction to that of Portland cement. The pozzolanic reactions are silica reactions in presence of calcium hydroxide (portlandite) and water to produce calcium silicate hydrates (Mindess S. et al., 2003; Hewlett P., 2004). Calcium hydroxides, which are one of Portland cement's hydration products, can also be produced by the SCM itself by combining its $\mathrm{CaO}$ with water (Papadakis V.G. et al., 1992).

The production of calcium silicate hydrates from a pozzolanic reaction contributes to concrete microstructure densification, to decrease porosity and to increase strength (Meddah M.S. and A. Tagnit-Hamou, 2009). The effect of SCM 's in concrete porous structure is strongly related with the composition of SCM and with water cement ratio (Diamond S., 2000). Additionally, for a pozzolanic reaction to take place it is necessary to perform a proper curing process ensuring water content (Malhotra V.M. and P.K. Mehta, 2005; Ayers M.E. and M.S. Khan, 1993).

Paste hydration studies performed by Berry E.E. et al. (1994) with type F fly ashes concluded that such SCM has a wide participation in hydration and cementitious reactions even at 180 days-ages. Besides, they found that the un-reacted fly ash helped to fill empty spaces in the micro-structure (densification). Another study (Jiang L. et al., 1999), concluded that although an increased amount of SCM may initially increase paste porosity, it decreases in with time, as SCM hydrates. They also conclude that there is a limit for cement replacement by SCM, so as to improve paste micro-structure.

The effect of SCM's on durability and particularly on concrete permeability, have been carefully studied. Dogan U.A. et al. (2009), measured chloride ion permeability in concrete of similar mixture designs but with different fly ash content; granulate blast furnace slag or silica fume content. Concrete were subjected to either air curing or moist curing. Results proved the relevance of curing procedure on permeability when SCM's were employed; 
the SCM content was more important in permeability reduction than water-cement ratio in concrete with SCM 's and moist curing.

A nother research (Uzal B. et al., 2007) that considered natural pozzolans, fly ashes and granulate blast furnace slag as SCM concluded that such SCM contribute to reduction in chloride ion permeability especially at 90 days of age. Chloride ion permeability at 90 days of age in SCM admixtures was between 6 and $14 \%$ compared to an admixture with no SCM content and with similar compressive strength. Gu P. et al. (2000) studied durability on SCM concretes and concluded that the use of SCM considerably reduced permeability to chloride ions compared to mixtures with no SCM 's, which was reflected by a higher protection to reinforced steel even with low coating surface.

\subsection{Research Significance}

Scientific motivation of this research is to quantify the contribution of natural pozzolans as far as permeability of concrete elaborated with Chilean cements is concerned. Therefore an experimental program was outlined, which enabled the characterization of permeability in concrete mixtures elaborated with cements containing different ratios of natural pozzolans.

\section{Experimental development}

\subsection{Constituent Materials}

Every mixture elaborated for this study considered the same type of aggregates and dosage, in order to obtain a constant particle size distribution. Fine-to-coarse aggregate ratio was 60/40, and the maximum size aggregate was $20 \mathrm{~mm}$. Physical properties of aggregates are shown in Table 1.

Tabla 1. Propiedades de los agregados Table 1. Aggregate Properties

\begin{tabular}{|l|c|c|c||}
\hline & Agregado Fino/Fine Aggregate & Agregado Grueso/ Coarse Aggregate & Combinado/Mixed \\
\hline Modulo de finura/Fineness Modulus & 4 & 6.66 & 5.06 \\
\hline Peso especifico/Specific Gravity & 2.63 & 2.65 & 2.64 \\
\hline Densidad aparente/Unit Weight [kg/m3] & 1430 & 1320 & \\
\hline Absorción/Absorption [\% ] & 1.4 & 1.8 & \\
\hline
\end{tabular}


In order to improve fresh concrete workability a plasticizer was employed, with a dosage $0.47 \%$ of cement weight. Target workability for each mixture was $6 \mathrm{~cm}$ approximately, which is measured by a slump test; however in some cases an adjustment was required by employing a hyper-plasticizer admixture.

This research considered three different cements: type I portland cement as per ASTM C-150 (OPOz), a blended cement comprised of Portland cement with a $14 \%$ natural pozzolans by weight (14Poz) and known as high early strength pozzolanic Portland cement and; blended cement comprised of Portland cement with a $33 \%$ natural pozzolans by weight (33Poz) known as pozzolanic cement. For the two blended cements the grinding of clicker occurs simultaneously with the natural pozzolans. Gypsum content varied between 2.7 and $3.5 \%$.

Table 2 shows the properties of cements employed in this research and Table 3 shows their approximate composition.

Tabla 2. Propiedades de los cementos utilizados Table 2. Properties of employed cements

\begin{tabular}{||l|c|c|c||}
\hline & \multicolumn{3}{|c|}{ Tipo Cemento/Type of cement } \\
\hline Finura ensayo blaine/Fineness Blaine test [m2/kg] & 360 & 523 & 454 \\
\hline Peso específico/Specific gravity & 3.18 & 2.96 & 2.83 \\
\hline tiempo fraguado inicial/Initial set time [min] & 150 & 130 & 132 \\
\hline tiempo fraguado final/Final set time [min] & 200 & 201 & 205 \\
\hline
\end{tabular}

Cement oxide's composition is among typical values, meanwhile natural ashes composition is close to that of type F fly ash, with no hydraulic activity and no pozzolanic activity.

Tabla 3. Composición de cementos y puzolana utilizada

Table 3. Percentage composition of employed cements and pozzolans

\begin{tabular}{||l|c|c||}
\hline & Cemento Portland/Portland Cement & Puzolana Natural/Natural Pozzolan \\
\hline Contenido/Content $\mathrm{SiO}_{2}[\%]$ & 20.8 & 67.9 \\
\hline Contenido/Content $\mathrm{Fe}_{3}[\%]$ & 2.9 & 1.8 \\
\hline Contenido/Content $\mathrm{Al}_{3}[\%]$ & 6.0 & 13.5 \\
\hline Contenido/Content $\mathrm{CaO}_{3}[\%]$ & 63.2 & 0.5 \\
\hline Contenido/Content $\mathrm{SO}_{3}[\%]$ & 1.8 & 2.2 \\
\hline
\end{tabular}




\subsection{Experimental methodology}

In order to measure the influence from cement type on permeability, an experimental methodology was applied, where the variable of interest was systematically changed (pozzolan content) and a response variable (permeability) is measured by different characterization methods. Therefore, dosages of total cementitious materials, water, coarse aggregate, fine aggregate and water reducer admixture were maintained constant and; only type of cement was changed. A particular nomenclature was used to characterize different concretes where letters indicate the type of cement $(33 \mathrm{Poz}=33 \%$ pozzolan cement, $14 \mathrm{Poz}=14 \%$ pozzolan cement and $\mathrm{OPOZ}=$ ordinary Portland cement) and numbers indicate water/cement ratio employed $(05=$ water cement ratio $0.5)$.

All mixtures contain $396 \mathrm{~kg} / \mathrm{m}^{3}$ cementitious material, $198 \mathrm{~kg} / \mathrm{m}^{3}$ water, $1036 \mathrm{~kg} / \mathrm{m}^{3}$ fine aggregate, $691 \mathrm{~kg} / \mathrm{m}^{3}$ coarse aggregate and plasticizing additive at $4 \%$ of cementitious materials weight rate.

O rdinary Portland cement has a faster hydration rate, which suggest to measure properties 28 days of age. $\mathrm{O} \mathrm{n}$ the other hand, cements containing pozzolan require longer time for pozzolanic reactions to take place, which suggest to measure properties 84 days of age. Therefore, the testing ages are 28 and 84 days, considering an intermediate age at 56 days. All test specimens are stored in a fog room until the age of testing.

Concrete mixtures were characterized by compressive strength and permeability, by employing the water permeability test as per DIN 1048 standard; chloride ion permeability as per ASTM C-1202 and; capillary absorption as per ASTM C-1585.

Compressive strength and chloride ion permeability tests are conducted at 28,56 and 84 days of-age. Capillary absorption and water permeability tests were conducted at 28 and 84 days of age, as well as for 33 Poz05 concrete at 56 days of age.

\section{Results and discussion}

\subsection{Compressive strength}

This testing was developed following ASTM C-39 specifications, by employing $20-\mathrm{cm}-$ cubic specimens (as per NCh 103-1977). 
Figurel shows the measured compressive strength versus time, where it is noticed that all concrete mixtures increased their compressive strength showing a similar behavior with time.

Figure 1 shows how the use of pozzolans replacement by Portland cement produces a significant concrete compressive strength reduction in the analyzed period of 28 to 84 days. At 28 days of age, 33Poz05 concrete strength is $31 \%$ lower than $0 \mathrm{Puz} 05$ strength while 14 Poz05 strength is $13 \%$ lower than OPoz05 strength. Such reduction percentages are similar to $33 \%$ and $14 \%$ pozzolans content in cement employed for $33 \mathrm{Poz} 05$ and 14Poz05, respectively. It suggests that at the age of 28 days pozzolan contribution is not noticeable yet.

In the period of 28 to 84 days the evolution of pozzolan concretes is slightly higher than that of ordinary portland cement. In the studied period, OPoz05 concrete shows only a $10 \%$ compressive strength increase compared to 28 days value, while $14 \mathrm{Poz} 05$ concrete increased its resistance in $14 \%$ and, $33 \mathrm{Poz} 05$ in $17 \%$. Consequently, differences among different concretes have decreased at 84 days of age.

At 84 days of age, 33Pz05 concrete has a compressive strength $27 \%$ lower than OPoz05 while the strength of $14 \mathrm{Poz} 05$ is $11 \%$ lower than OPoz05. Although strength differences are still significant at the age of 84 days a pozzolan contribution is detected with respect to 28-days values.

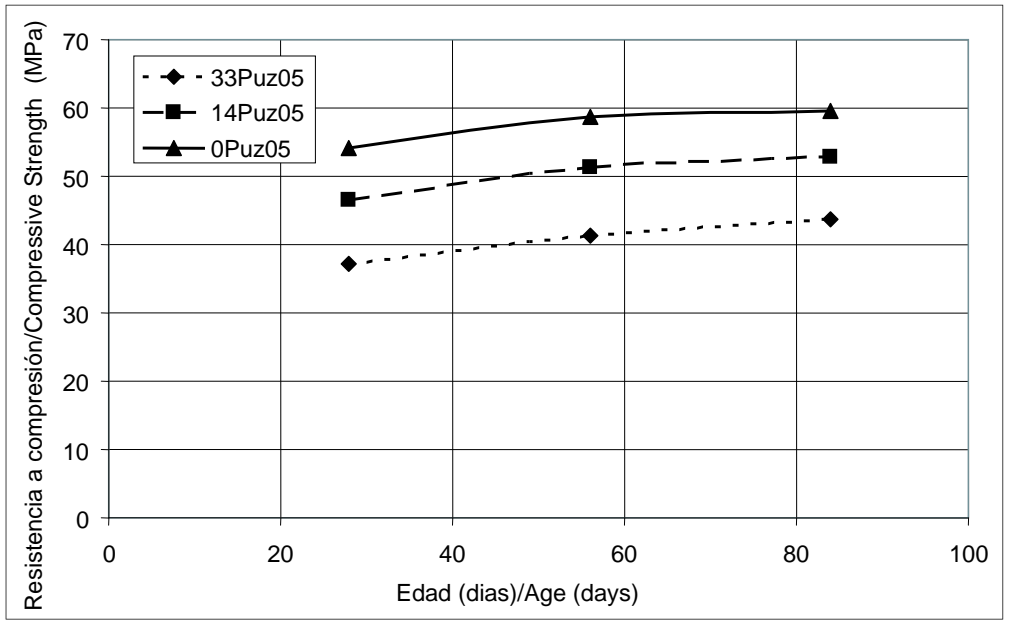

Figura 1. Evolución de resistencia según contenido de puzolanas Figure 1. Strength gain according to pozzolan content 
The cements employed in this research, besides having different pozzolan contents, they also have differences in Blain Fineness (Table 2). It implies that higher fineness cement (i.e. 14Poz05) will have a higher hydration rate at early and middle age (28 days or less) than coarser grinded cements (i.e., 33Poz05); this effect decreases or even disappears at late ages (84 days or more). Then it is necessary to thoroughly analyze results obtained at the age of 28 days, as results would be affected by fineness differences of cements at a higher extent.

Therefore, it can be concluded that 0Poz05 mixture (with the coarser cement) would have showed higher 28-day compressive strength, and would have kept its 84-day compressive strength, in case of having had the same finenesses as 33Poz05 and 14Poz05 mixtures. This would have increased the differences of strength gain rates with time, which were observed among ordinary portland cement and blended cement with natural pozzolans.

\subsection{Chloride ion permeability test}

Chloride ion permeability test consists in measuring electrical charge passing during a given period of time, under an imposed potential difference which forces chloride ion migration through a concrete test specimen.

As shown in Figure 2, at 28 days there is no significant difference regarding passing charge among the concrete mixtures under study. The 0Poz05 concrete has lower chloride ion permeability than 33Poz05 and 14Poz05. The three concrete mixtures are classified as high chloride ion permeability in accordance with the standard. As the test age increases, there is a decrease in chloride ion permeability.

Although three concretes show high permeability at 56 days, it is observed that 33Poz05 and 14Poz05 concretes come close to 4000 Coulombs, which is the classification limit for moderate permeability. OPoz05 concrete showed a smaller reduction in its permeability between 28 and 56 day; thus, becoming the most permeable of three concrete mixtures under study.

In the period of 56 to 84 days of age, concretes still show a reduction in permeability with 0Poz05 concrete, having the lowest reduction rate. At 84 days it can be observed that concretes containing natural pozzolans (33Poz05 and 14Poz05) show a moderate permeability while pure Portland concrete (OPOz05) kept a high permeability. 
In overall terms concrete mixtures containing pozzolans show a clear difference in time variation compared to concrete with no pozzolans. Although pozzolan concretes have a quite similar behavior, it is observed that concrete mixture having more pozzolan content (33Poz05) has the most significant reduction in the period between 28 and 84 days of age, in comparison to the concrete having less pozzolan content (14Poz05).

It is important to point out that conclusions hereby obtained consider comparisons between concretes having different fineness rates (Table 2). Taking in to consideration that fineness differences are relevant at early and middle ages, it can be concluded that 0Poz05 mixtures (lower fineness cement) would have yielded lower permeability at 28 days and would have maintained their permeability at 84 days in case of having had higher finenesses as 33Poz05 and 14Poz05. This would have shown even lower permeability reduction in 0Poz05 mixture between 28 and 84 days by accentuating the pozzolan incorporation effect on chloride ion permeability with time.

The presence of pozzolan in 33Poz05 and 14Poz05 concretes enables lower permeability to chloride ion and higher reduction of such property provided that pozzolan content is higher, in terms of time. Such results match results by Mehta P.K. and P.J.M. Monteiro (2006) who concluded that at 90 days or more an ordinary portland cement concrete generally yields 2500 Coulombs more chloride ion permeability than a concrete containing SCM 's. In this research differences between 0Poz05 and mixtures with pozzolan were 2900 Coulombs.

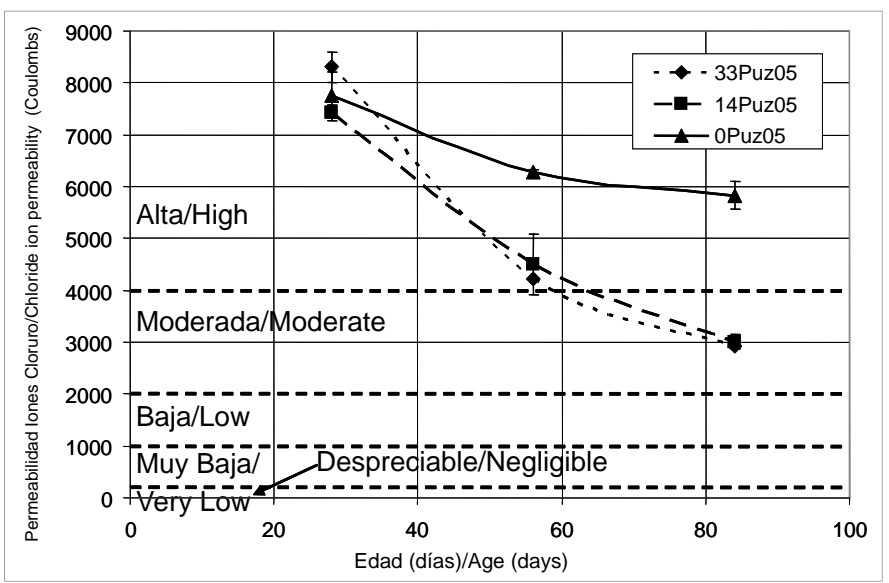

Figura 2. Evolución de permeabilidad de iones cloruros según contenido de puzolanas

Figura 2. Chloride ion permeability change according to pozzolan content 
Therefore, it is concluded that pozzolan plays an important role regarding concrete permeability from a chloride ion permeability point of view. It is deducted that pozzolan enables the production of a dense microstructure having a non-continuous pore network which makes difficult chloride ion penetration into concrete.

A research (Cortes M., 1997) conducted a chloride ion permeability test on mixtures quite similar to the ones analyzed by this study, but at 266 days of age.

Results obtained by 33Poz05, 14Poz05 and OPoz05 were 418, 1236 and 3275 Coulombs, respectively, which confirms permeability reduction trend observed between 28 and 84 days of age. Mixtures with higher pozzolan contents continued decreasing their chloride ion permeability in a sizable way. Moreover, such reductions are related with pozzolan contents. Therefore, after 266 days of age, 33Poz05 and 14Poz05 mixtures have a permeability equivalent to 12.7 and $37.7 \%$ compared to concrete mixtures with ordinary portland cement with no pozzolan, respectively.

\subsection{Water permeability test}

Water permeability test measures water penetration depth into concrete, when it is subjected to pressures between 0.1 and $0.7 \mathrm{MPa}$ during a 4-day period. Figure 3 depicts the average behavior with time, besides the results of standard variation in each concrete is also indicated.

It is important to point out that variations among test specimens (Figure 3 ) is a relevant factor in relation with average variations measured for concrete made of different types of cements and at different ages. It is concluded that, although a permeability reduction with time was observed, they are not significant differences and the test method accuracy is limited. Test variation coefficients were located between 10.3 and $33.3 \%$, with an average of $22 \%$. Therefore, it is observed that $33 \mathrm{Poz} 05$ concrete shows a permeability increase between 56 and 84 days, which is not possible from concrete hydration point of view.

Water permeability test shows high variability which makes it a non-accurate permeability indicator. The use of water in pressure ranges considered by this study, might be leading to damage in pore structure for the cement paste, and therefore it could be increasing concrete porosity and permeability. 
Since this is an accelerated test and does not represent concrete's typical servicing exposure conditions, it is concluded that this trial is not adequate to evaluate water permeability in concrete.

\subsection{Capillary absorption test}

This test was conducted in accordance with ASTM C-1585 standard. This test consists of measuring capillary absorption rate in a pre-conditioned test specimen, where its absorption water area is limited. The test indirectly measures pore connectivity in concrete structure. Table 4 shows initial capillary absorption coefficient, as per ASTM C-158.5 in a period from 0 to 6 hours. Such coefficient indicates a curve slope between the increased mass of test specimen per area unit (produced by water capillary absorption) and square root of time.

From Table 4, it can be observed that 33Poz05 as well as OPoz05 show the highest capillary absorption coefficients at 28 days, in contrast to 14 Poz05 mixture which shows a value approximately $20 \%$ lower than the previous ones. Cement fineness employed by 14Poz05 and its consequent higher hydration, may partly explain lower initial absorption coefficient shown by such concrete. This might be caused by a lower pore connectivity compared to the other two mixtures.

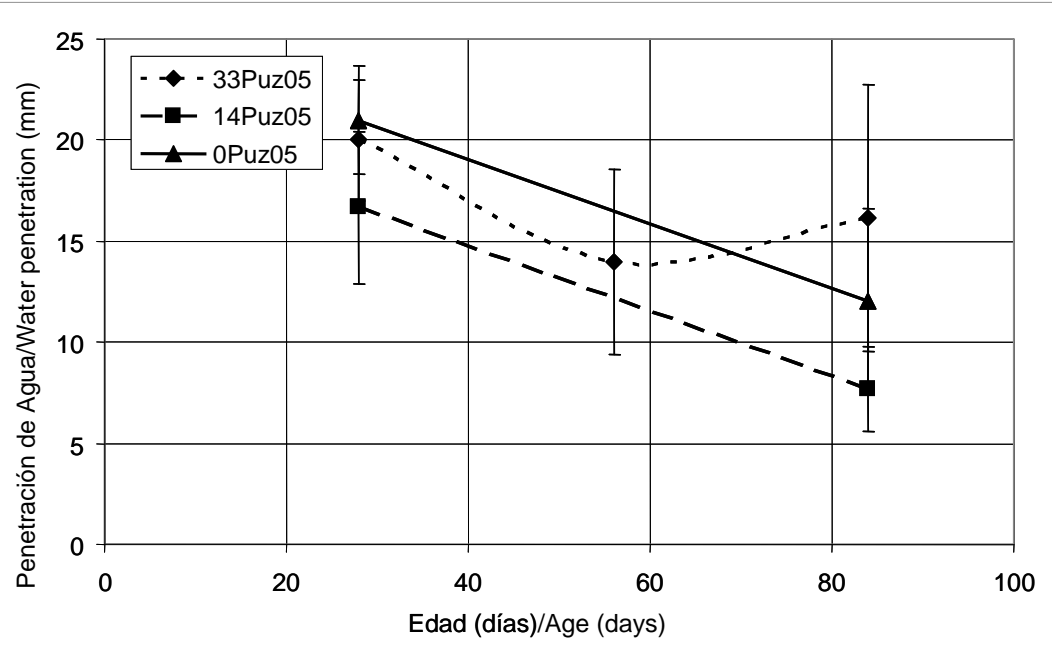

Figura 3. Evolución de la permeabilidad al agua según contenido de puzolanas Figure 3. Water permeability change according to pozzolan content 
Tabla 4. Coeficiente inicial de absorción capilar

Table 4. Initial capillary absorption coefficient

\begin{tabular}{|l|c|c|}
\hline & Coeficiente inicial de absorción capilar/Initial capillary absorption coefficient $\left[\mathrm{kg} / \mathrm{m}^{2} \mathrm{~s}^{0.5}\right.$ \\
\hline & 28 días & 84 días \\
\hline 33Puz05 & $9.2 \times 10^{-3}$ & $6.6 \times 10^{-3}$ \\
\hline 14Puz05 & $6.8 \times 10^{-3}$ & $6.5 \times 10^{-3}$ \\
\hline OPuz05 & $8.5 \times 10^{-3}$ & $5.4 \times 10^{-3}$ \\
\hline
\end{tabular}

However, between 28 and 84 days of age, 33Poz05, 14Poz05 and 0Poz05 mixtures show an initial capillary coefficient reduction of $35 \%, 22 \%$ and $25 \%$, respectively.. It is concluded that higher natural pozzolan content in 33Poz05 mixture enabled a pore connectivity decrease in a more effective way than 14Poz05 and OPoz05.

\section{Conclusions}

From results analysis of this study, that compared performance of concrete with different natural pozzolan contents, it can be concluded:

0 Water permeability test assessed by this research was concluded to be non-accurate and unclear, showing important results variability. Since this is an accelerated trial with pressures up to $0.7 \mathrm{MPa}$, which does not represent concrete typical exposure servicing conditions, it is concluded that this is not an adequate test for assessing concrete permeability.

o Chloride ion permeability test provides consistent low variability results which properly represent pozzolan contribution to concrete permeability.

o Capillary absorption test provides consistent results that properly reflect pore connectivity decrease taking place while pozzolans hydrate.

0 The highest chloride ion permeability reduction, from 28 to 84 days, is shown by $33 \mathrm{Poz} 05$ concrete $(33 \%$ pozzolan content) that reached $65 \%$; 14Poz05 concrete (14\% pozzolan content) decreased its permeability in $60 \%$ and; finally 0Poz05 concrete $(0 \%$ pozzolan content) only showed a $25 \%$ reduction. 
o Pozzolan have a more outstanding contribution to permeability reduction than to strength gain. This is because hydration products from natural pozzolans mainly contribute to reduce pore connectivity in a concrete structure; thus, making the transportation into micro-structure more difficult.

o Based on results obtained by this study, the effect of natural pozzolans is much more significant on permeability reduction than on strength gain. Therefore, specifying concrete durability by means of strength, or expecting durability increase due to higher strength, is a mistake when natural pozzolans are used.

- Results indicate that properties at 84 days are not stabilized yet, so development and improvement of concrete properties should increase with time, above all permeability for high pozzolan content concretes.

\section{Acknowledgements}

This research was financed thanks to Fondecyt Regular Project 11060341. Special thanks to RESM ATDICTU C staff for their support.

\section{Referencias / References}

Ayers M.E. y M.S. Khan (1993), O verview of Fly Ash and Silica Fume Concretes: The Need for Rational Curing Standards. in Proceedings of V. Mohan Malhotra Symposium. 1993: American Concrete Institute.

Berry E.E., R.T. Hemmings, M.H. Zhang, B.J. Cornelius y D.M. Golden (1994), Hydration in High-Volume Fly Ash Concrete Binders. ACI Material Journal, 1994. 91(4): p. 382-389.

Cortes M . (1997), Penetración de Cloruros en el Hormigón, influencia de la Composición y de la Pasta Aglomerante. 1997, Universidad de Chile: Santiago. Diamond S. (2000), Mercury Porosimetry: An Inappropriate Method for the Measurement of Pore Size Distribution in Cement-Based Materials. Cement and Concrete Research, 2000. 30(10): p. 1517-1525.

Dogan U.A., E.B. Kurt, A.G. Saran y M.H. Ozkul (2009), Benchmarking Concretes with Pozzolanic Materials in Terms of Rapid Chloride Penetration Test. ACI Material Journal, 2009. 106(3): p. 251-257.

Gu P., J.J. Beaudoin, M.H. Zhang y V.M. Malhotra (2000), Performance of Reinforcing Steel in Concrete Containing Silica Fume and Blast-Furnance Slag Ponded with Sodium-Chloride Solution. ACI Material Journal, 2000. 97(3): p. 254-262.

Hewlett P. (2004), Lea's Chemistry of Cement and Concrete. 4th ed. 2004, Burlington: Butterworth-Heinemann. 1092. Jiang L., B. Lin, y Y. Cai (1999), Studies on Hydration in High-Volume Fly Ash Concrete Binders. ACI Material Journal, 1999. 96(6): p. 703-706. Malhotra V.M. y P.K. M ehta (2005), High-Performance, High-Volume Fly Ash Concrete: Materials, Mixture Proportions, Properties, Construction Practice, and Case Histories. 2nd ed. 2005, O ttawa: Supplementary Cementing Materials for Sustainable Development Inc.

Meddah M .S. y A. Tagnit-Hamou (2009), Pore Structure of Concrete with Mineral Admixtures and Its Effect on Self-Desiccation Shrinkage. ACI Material Journal, 2009. 106(3): p. 241-250.

Mehta P.K. y P.J.M. Monteiro (2006), Concrete : microstructure, properties, and materials. 3rd ed. 2006, New York: McGraw-Hill. xxi, 659 p. Mindess S., J.F. Young y D. Darwin (2003), Concrete. 2nd ed. 2003: Prentice Hall.

N eville A.M. (1996), Properties of concrete. 4th and final ed. 1996: J. Wiley.

Papadakis V.G., M.N. Fardis y C.G. Vayenas (1992), Hydration and Carbonation of Pozzolanic Cements. ACI Material Journal, 1992. 89(3): p. 119-130. Uzal B., L. Turanli y P.K. Mehta (2007), High-Volumne Pozzolan Concrete for Structural Applications. ACI Material Journal, 2007. 105(5): p. 535-538. 